\title{
THE RELATIONSHIP BETWEEN THE LEVEL OF PHYSICAL ACTIVITY, INDEPENDENCE IN DAILY ACTIVITIES, AND LIFE QUALITY AND SATISFACTION IN WOMEN OVER 80 LIVING IN RURAL AREAS - A PILOT STUDY
}

\author{
Grzegorz Żurek', Ewelina Lepsy², Alina Żurek, Alina Radajewska \\ Kuba Ptaszkowski ${ }^{5}$, Magdalena Golachowska ${ }^{6}$
}
${ }^{1}$ Department of Biostructure, University School of Physical Education, Wroclaw, Poland
${ }^{2}$ Department of Physiotherapy, Opole Medical School, Opole, Poland
${ }^{3}$ Department of Clinical Psychology and Health, University of Wroclaw, Wroclaw, Poland
${ }^{4}$ Department of Physiotherapy, Krapkowice Health Centre, Krapkowice, Poland
${ }^{5}$ Department of Clinical Biomechanics and Physiotherapy in Motor System Disorders,
Faculty of Health Science, Wroclaw Medical University, Wroclaw, Poland
${ }^{6}$ Department of Health Sciences, Opole Medical School, Opole, Poland

\begin{abstract}
Background. Better medicine and health care steadily increases the human life expectancy. Growing number of elderly people and the imbalance of population structure will affect many fields of life, including social security system, joborientation and culture. Therefore it is crucial that the elderly maintain not only good physical health but keep the ability to self-care as long as possible, stay functionally fit and express satisfaction of life in all domains.

Objective. This study aims to analyse the factors that affect the quality of life in different domains (physical, psychological, social and environmental), like the independence in performing everyday life activities and the level of physical activity of women above 80 years old, living in own households.

Materials and methods. The study was performed from March to August 2015 in Opole, Lower Silesia and Silesia voivodeship, mosty in rural areas, on 67 women, age above 80 (average 82.9), who filled the standarized questionnaires of life quality (WHOQOL-BREF), physical activity (IPAQ), and self-maintenance in daily living (IADL, Lawton scale). Results. The results show that the life satisfaction of women above 80 years old living in own households in rural areas is highest in the social and environmental domains, while is the lowest in physical health domain. There is a strong positive correlation between the level of physical activity, the level of self-maintenance and the life quality in four of its domains. Conclusions. Self-maintenance and higher level of physical fitness, which are the components of functional fitness, positively correlate with self-assesed life-satisfaction in all domains. It is crucial to stress the importance of physical activity in seniors, preferably in way of dedicated exercising of moderate and high intensity, that will bring benefits not only in domain of physical health but in overall well-being and higher life-satisfaction, the significant factors in healthy ageing.
\end{abstract}

Key words: senior physical activity, functional fitness, senior self-maintenance, quality of life of elderly

\section{STRESZCZENIE}

Wprowadzenie. Rosnący poziom opieki zdrowotnej stale zwiększa długość życia ludzi. Rosnąca liczba osób starszych i zaburzenie równowagi w strukturze populacji wpłynie na wiele dziedzin życia, w tym na system ubezpieczeń społecznych, orientację zawodową osób pracujących czy kulturę. Dlatego bardzo ważne jest, aby osoby starsze zachowały nie tylko dobre zdrowie fizyczne, ale także utrzymywały zdolność do samoopieki tak długo, jak to możliwe, pozostały sprawne funkcjonalnie i wyrażały zadowolenie z życia we wszystkich dziedzinach.

Cel. Niniejsze badanie ma na celu analizę czynników wpływających na jakość życia w różnych dziedzinach (fizyczna, psychologiczna, społeczna i środowiskowa), takich jak niezależność w wykonywaniu codziennych czynności oraz poziom aktywności fizycznej u kobiet w wieku powyżej 80 lat, mieszkających we własnych gospodarstwach domowych.

Material i metody. Badanie przeprowadzono od marca do sierpnia 2015 r. w województwach opolskim, dolnośląskim i śląskim, głównie na wsi, na 67 kobietach w wieku powyżej 80 lat (średnia 82,9), które wypełniły standaryzowane kwestionariusze dotyczące jakości życia (WHOQOL-BREF), aktywności fizycznej (IPAQ) i samowystarczalności w życiu codziennym (IADL, skala Lawtona).

Corresponding author: Magdalena Golachowska,PhD., Państwowa Medyczna Wyższa Szkoła Zawodowa w Opolu, Wydział Nauk o Zdrowiu, ul. Katowicka 68, Opole, tel. +48 511868 421, e-mail: golachowskam@wsm.opole.pl

(C) Copyright by the National Institute of Public Health - National Institute of Hygiene 
Wyniki. Wyniki naszego badania pokazują, że zadowolenie z życia kobiet w wieku powyżej 80 lat mieszkających we własnych domach na obszarach wiejskich jest najwyższe w domenie społecznej i środowiskowej, a najniższe w dziedzinie zdrowia fizycznego. Istnieje silna dodatnia korelacja między poziomem aktywności fizycznej, poziomem samodzielności a jakością życia w czterech jej dziedzinach.

Wnioski. Samodzielność i wyższy poziom sprawności fizycznej, które są składnikami sprawności funkcjonalnej, pozytywnie korelują z ocenianą satysfakcją życiową we wszystkich jej dziedzinach. Bardzo ważne jest podkreślenie znaczenia aktywności fizycznej u seniorów, zwłaszcza w formie dedykowanych ćwiczeń o umiarkowanej i wysokiej intensywności, co może mieć korzyści nie tylko w dziedzinie zdrowia fizycznego, ale także w ogólnym lepszym samopoczuciu i większym zadowoleniu z życia, które są podstawami zdrowego starzenia się.

Slowa kluczowe: aktywność fizyczna seniorów, sprawność funkcjonalna, samodzielność seniorów, jakość życia seniorów

\section{INTRODUCTION}

Growing number of studies published in recent decades show the increase in human life expectancy. The developments in medicine, better nutrition and more available health care have led to decrease in mortality rate from injuries, infections and noncommunicable diseases [44].

These facts, together with decrease in number of births, lead to the process of doubling the aging population, which involves an increase in the total segment of seniors as well as the subpopulation of very elderly persons (aged 80 and more). Demographers predict that by 2060 the number of people aged 80 and over will double in European countries. In Germany, Slovakia, Spain, Portugal and Greece, the proportion of these people will be $13.4-16.1 \%$ of the total population, and in Poland will be $12.3 \%$.

The process of ageing depends mostly on decrease in effectiveness of metabolic processes over time, accumulation of errors (eg. more DNA damage, more dysfunctional proteins' deposits) and worse regeneration, which influence the functionality of each cell, tissues and organs, leading to organ failure and eventually death [22]. Better health care and better medicines may help to extend life in terms of physical health. However it is important to take into account other domains of health as well as overall wellbeing and life satisfaction of elderly [11, 18, 43].

According to the World Health Organization (WHO), quality of life is defined as "the individual's perception of their position in life in the context of the culture and value systems in which they live and in relation to their goals" [19]. To assess the life quality of late age seniors the state of not only physical, but also emotional and social health has to be taken into account. These factors are reflected in the feeling of happiness, cognitive functions, self-vision, coping with environment changes and growing limitations of the body $[23,38]$.

According to many studies [7, 29, 30, 39] the quality of life correlates, beside the type of disorder, disease length, treatment and its side effects, also with gender, education, relations with family and friends, place of residence (own household or senior houses). It also includes maintaining functional fitness, which is the independence from others in satisfying basic life needs or the ability to self-care, like mobility, nutrition, personal hygiene and control over physiological urges. In many studies it is indicated that functional fitness is one of the most important factors influencing the life satisfaction. However with age, activities of elderly shift from regular and intensive to low impact activities like walking and housekeeping duties, leading to more sedentary life style [32, 34].

Nowadays, studying the components that affect the overall sense of life satisfaction in growing population of elderly is very important. It is worth stressing that seniors who score higher at self-assessed life quality are more independent, need less care from others (family members and health care staff), recover faster and have less age-related diseases [21].

Our research focuses on several domains related to life satisfaction in women over the age of 80 , such as physical, psychological, social and environmental health. We also tried to find important components that are associated with it, i.e. independence in the performance of daily duties and level of physical activity.

\section{MATERIALS AND METHODS}

The study was conducted on 67 women from three voivodships in Poland (Opole, Lower Silesia, Silesia), from March to August 2015. The including criteria were:

- age over 80 years old on the day of the study

- ability to logically and independently answer the questions,

- living alone or with family in own household

- informed consent to participate in the research. Participants were asked to answer three validated questionnaires, translated to Polish language:

- WHOQOL-BREF (World Health Organisation Quality of Life questionnaire)

- IPAQ (International Physical Activity Questionnaire) - short version 
- Lawton Scale (The Lawton Instrumental Activities of Daily Living, IADL)

WHOQOL-BREF (World Health Organisation Quality of Life Questionnaire) is often used in national and international studies to assess the psychometric quality of life. It consists of four sections related to four domains of live and two questions on individual perception of the quality of life (global quality of life) and individual, overall perception of one's own health (self-assessment of one's health) [16].

The aspects measured in four domains related to quality of life are:

- in the physical domain: limitations related to pain, level of energy, dependence on medical treatment, satisfaction with sleep, efficiency in everyday life, readiness to work;

- in the psychological domain: meaning and joy of life, concentration, self-esteem, negative and positive feelings;

- in the social domain: relations with the environment and social support, intimate life;

- in the environmental domain: a sense of security, access to health care, material and housing conditions, access to information and pursuit of interests, access to public transportation

Scoring in each domain has a positive direction, so the higher the number of points, the better the quality of life [16].

IPAQ (International Physical Activity Questionnaire) was used to measure the level of physical fitness in form of the energy expenditure for activity per week (MET-min/week) [3]. In this study we used the shortened version cosisting of 7 questions relating to all variants of physical activity associated with everyday life, work and leisure. The respondent provides answers about the time spent sitting, walking and the time spent on moderate and intense physical effort. The type of physical activity was expressed using the Metabolic Equivalent of work, MET. It is calculated as the ratio of the coefficient assigned to a given physical activity (intensive, moderate and low), the number of days it is performed per week and the duration in minutes per day. In this way, the average value of physical activity expressed in MET units [min / week] is obtained for each of three levels of physical activities [3].

Lawton Scale (The Lawton Instrumental Activities of Daily Living, $I A D L)$ was used to assess the selfmaintenance in daily living and independence in complex everyday activities [13,24].

It consists of 8 questions assessing the performance of household chores such as cleaning, cooking, washing; ability to shop and use the available means of transport, use of the telephone, ability to manage money, proper use of medicines. Being completely independent of the others, the respondent received a maximum of 8 points.

\section{Statistics}

The collected test results were subjected to statistical analysis with Statistica 12 (StatSoft, Inc., USA). The normality of variable distribution was assessed using the Shapiro-Wilk test. For the parameters for which there were no grounds to reject the hypothesis of normal distribution, mean values $(\bar{x})$, standard deviation (s) were calculated. In turn, for parameters where the hypothesis with normal distribution was rejected, the median, quartiles (lower and upper), minimum and maximum were calculated. The significance of differences between the average values was assessed by the Student's t test. The MannWhitney U test was used to show significant differences between groups. The Pearson's correlation coefficient (for normal distribution) and Spearman's rank correlation coefficient (for distribution that deviates from normal) were used to assess relationships.

The level $\alpha=0.05$ was assumed as statisticaly significant for all analyzes and the obtained values of "p" were rounded to 4 decimal places.

The study was approved by the Bioethics Commitee of Opole Medical School (nr 3/2015).

\section{RESULTS}

The study was completed by 67 women, aged $80-90$ (median age 82.9). Most of participants were widows (78\%), living independently in their own households in rural areas (73\%), who used to perform physical work in the past (78\%). Detailed description of the group is depicted in Table 1.

Table 1. Detailed characteristics of tested group

\begin{tabular}{|c|c|c|}
\hline \multicolumn{3}{|c|}{ Women $(n=67)$} \\
\hline & average & $\begin{array}{l}\text { standard } \\
\text { deviation }\end{array}$ \\
\hline Age [years] & 82.94 & 2.67 \\
\hline Body height [cm] & 157.9 & 5.53 \\
\hline Body weight [kg] & 68.49 & 9.94 \\
\hline BMI $\left[\mathrm{kg} / \mathrm{m}^{2}\right]$ & 27.46 & 3.85 \\
\hline $\begin{array}{l}\text { Type of work performed in } \\
\text { the past }\end{array}$ & \multicolumn{2}{|c|}{$\begin{array}{c}\text { physical }-78 \% \\
\text { intelectual }-22 \%\end{array}$} \\
\hline Marital status & \multicolumn{2}{|c|}{$\begin{array}{c}\text { unmarried }-7 \% \\
\text { married }-15 \% \\
\text { widow }-78 \%\end{array}$} \\
\hline Place of residence & \multicolumn{2}{|c|}{$\begin{array}{l}\text { rural area }-73 \% \\
\text { town or city }-27 \%\end{array}$} \\
\hline
\end{tabular}




\section{WHOQOL-Bref}

The results of life-quality questionnaire in each of four domains and self-assessed overall life-quality are shown in Table 2. The highest scores were obtained in social and environmental domains, then the psychological domain, while the physical domain had the lowest score.

The respondents scores, represented as the average percentage of the total sum in each of four domains, are depicted in Figure 1.
For further analysis, the studied women were divided into two age groups: younger (up to 85 years old) and older ( 85 years old and over). It was established that younger women assess higher scores on their quality of life in all the domains studied, their global quality of life and self-assessment of their health. In addition, the analysis showed the significance of differences between the age groups in physical, psychological domains and self-assessment of one's health (Table 3, Figure 2 and Figure 3).

Table 2. Results of the WHOQOL-BREF questionnaire

\begin{tabular}{|l|c|c|c|}
\hline \multirow{2}{*}{$\begin{array}{c}\text { WHOQOL-BREF } \\
\text { questionnaire questions and domains }\end{array}$} & $\begin{array}{c}\text { questions rate } \\
\text { (points) }\end{array}$ & Respondends score $(\mathrm{n}=67)$ \\
\cline { 3 - 4 } global quality of life & $1-5$ & 3.81 & SD \\
\hline self-assessment of one's health & $1-5$ & 3.42 & 0.94 \\
\hline physical domain & $7-35$ & 24.27 & 1.02 \\
\hline psychological domain & $6-30$ & 22.84 & 5.62 \\
\hline social domain & $3-15$ & 11.67 & 4.55 \\
\hline environmental domain & $8-40$ & 31.08 & 1.85 \\
\hline
\end{tabular}

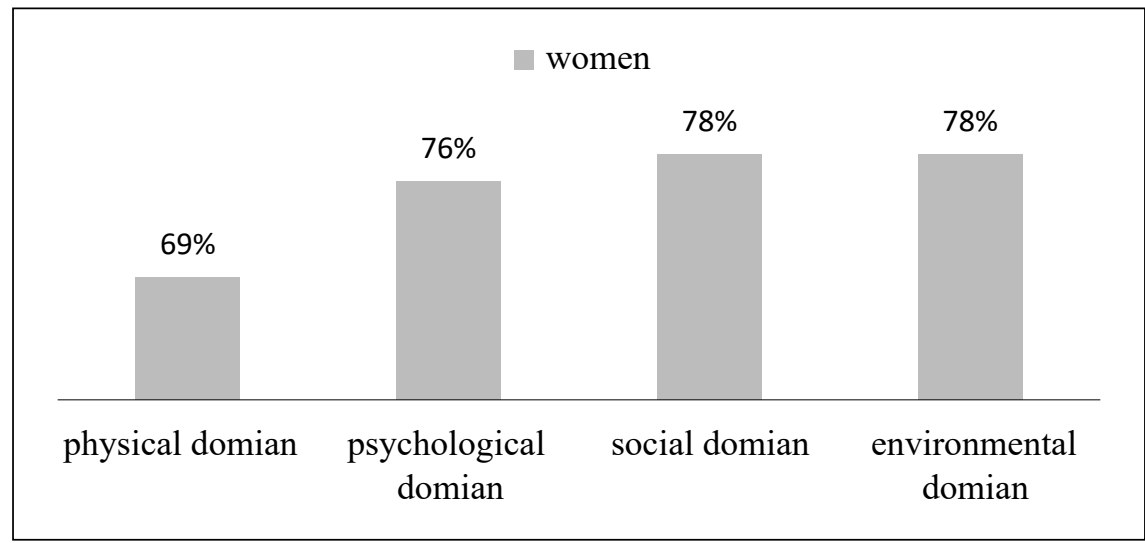

Figure 1. Percentage characteristics of assessments in four domains of the WHOQOL-BREF questionnaire

Table 3. Statistical characteristics and comparison of means between a group of younger (up to 85 years old) and older women ( 85 years old or more) ( $p$ values $<0.05$ are marked in bold)

\begin{tabular}{|c|c|c|c|c|c|c|c|}
\hline \multirow[t]{2}{*}{ WHOQOL-BREF } & \multirow[t]{2}{*}{$\begin{array}{l}\text { questions } \\
\text { rate } \\
\text { (points) }\end{array}$} & \multicolumn{2}{|c|}{$\begin{array}{l}\text { Women } \\
\text { up to } 85 \text { years } \\
(\mathrm{n}=54)\end{array}$} & \multicolumn{2}{|c|}{$\begin{array}{c}\text { Women } 85 \\
\text { or more years } \\
(n=13)\end{array}$} & \multicolumn{2}{|c|}{ t-Student's test } \\
\hline & & average & SD & average & SD & $\mathrm{t}$ & $\mathrm{p}$ \\
\hline global quality of life & $1-5$ & 3.91 & 0.93 & 3.38 & 0.87 & 1.83 & 0.0719 \\
\hline self-assessment of one's health & $1-5$ & 3.55 & 1.00 & 2.84 & 0.90 & 2.33 & 0.0228 \\
\hline physical domain & $7-35$ & 25.17 & 5.36 & 20.53 & 5.28 & $2, .9$ & 0.0067 \\
\hline psychological domain & $6-30$ & 23.48 & 4.46 & 20.15 & 3.99 & 2.6 & 0.0166 \\
\hline social domain & $3-15$ & 11.87 & 1.77 & 10.84 & 2.03 & 1.82 & 0.0734 \\
\hline environmental domain & $8-40$ & 31.46 & 4.98 & 29.46 & 368 & 1.36 & 0.1796 \\
\hline
\end{tabular}




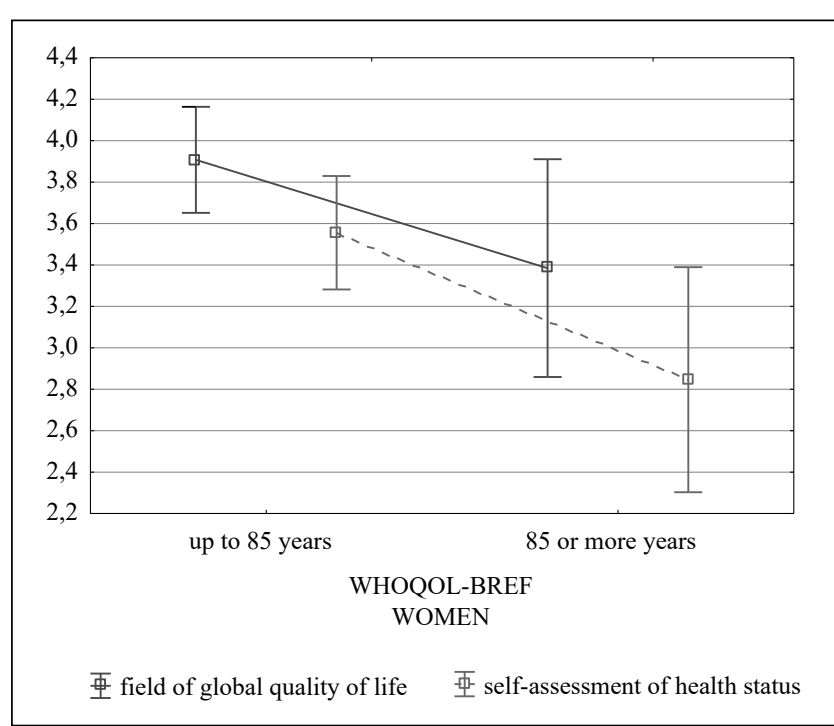

Figure 2. Statistical characteristics of assessments in the field of global quality of life and self-assessment of health status of two age groups of women surveyed

\section{IPAQ - physical activity level}

IPAQ was used to measure the level of physical fitness in form of the energy expenditure for activity per week (MET-min/week) [3]. The results of IPAQ were analysed with non-parametric statistical tests because the variables do not meet the assumption of normal distribution.

Less than $25 \%$ of surveyed women showed intensive physical activity over the past 7 days. Intensive activity means a kind of effort that significantly increases breathing and accelerates heart rate, but it should be noted that in this questionnaire the intensity of the effort was self assesed by the respondents, and therefore is subjective. The averge physical activity, which requires average effort with slightly increased breathing and increased heart rate, was indicated by $50 \%$ of the senior women. Almost all respondents declared low activity (walking that lasted at least 10 minutes at a time) (Table 4). Additionally, it was observed that an older group of women (above 85

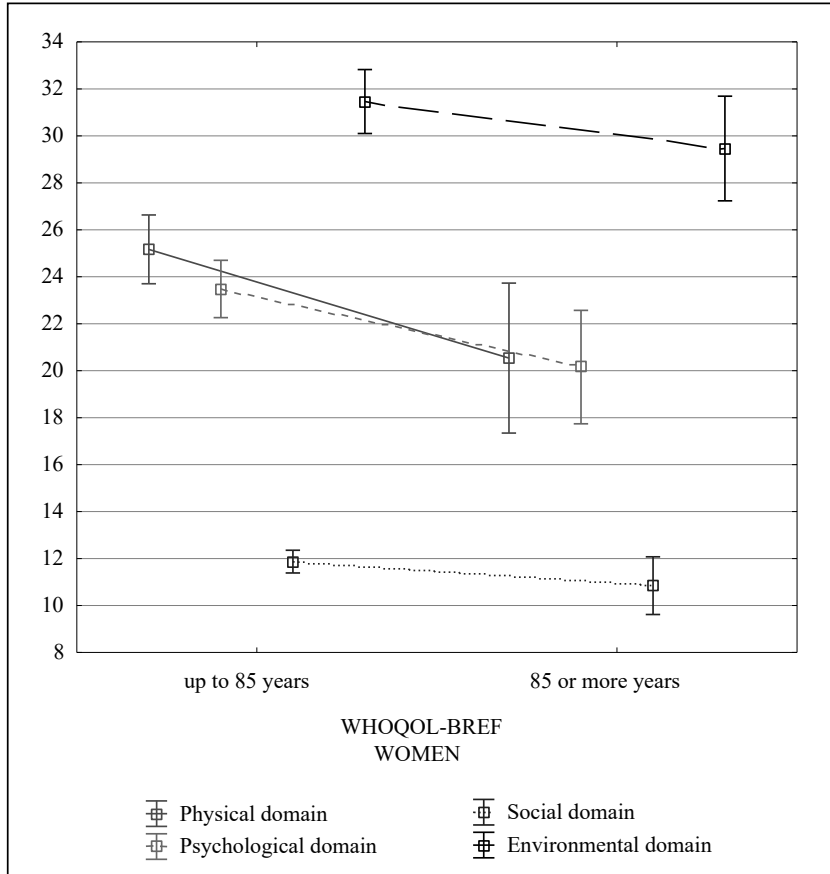

Figure 3. Statistical characteristics of assessments in the four domains of quality of life of two age groups of women surveyed

y.o.) showed lower levels of moderate and low physical activity (Figure 4).

\section{IADL (Lawton Scale)}

The self-maintenance (independence) in daily living was assesed with the Lawton Scale (The Lawton Instrumental Activities of Daily Living, IADL) [13, 24]. The scale rates $0-8$ points. The results of IADL were analysed with non-parametric statistical tests because the variables do not meet the assumption of normal distribution.

In the examined group of women $50 \%$ scored 7 points or less, the other half obtained the maximum number of 8 points. The results indicate that most of the surveyed seniors are independent and do not require help in everyday activities (Table 4). Analysis of Lawton's Scale results due to the age of the women surveyed showed that younger women (up to 85 years old) are more independent then older ones (85 years and older) (Figure 5).

Table 4. Results of the IPAQ and Lawton Scale questionnaires

\begin{tabular}{|c|c|c|c|}
\hline \multirow[b]{2}{*}{ Questionnaires } & \multicolumn{3}{|c|}{ Respondends score $(n=67)$} \\
\hline & Median & $\begin{array}{c}\text { lower } \\
\text { quartile }\end{array}$ & $\begin{array}{c}\text { top } \\
\text { quartile }\end{array}$ \\
\hline IPAQ - high activity [MET-min] & 0.0 & 0.0 & 5760 \\
\hline IPAQ - moderate activity [MET-min] & 240 & 0.0 & 3360 \\
\hline IPAQ - low activity (walking) [MET-min] & 693.0 & 0.0 & 8316 \\
\hline IADL (Lawton's Scale) [scores 0-8] & 7.0 & 0.0 & 8.0 \\
\hline
\end{tabular}




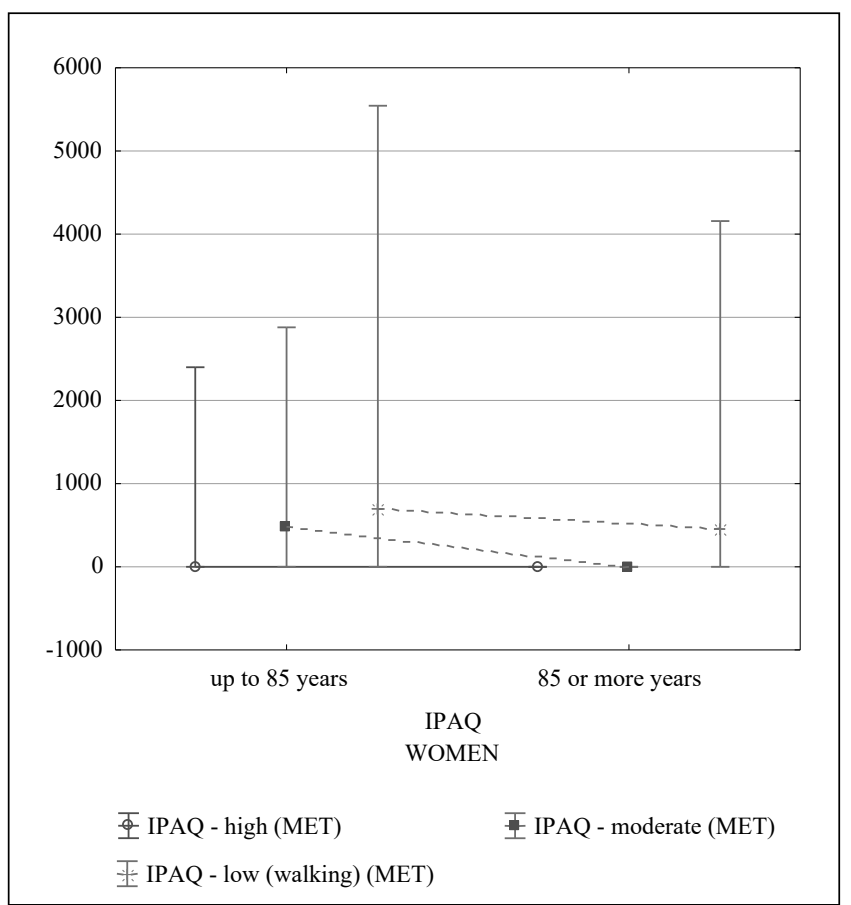

Figure 4. Statistical characteristics of the level of physical activity for two age groups of women surveyed

The cross-analysis of assessment of quality of life in all four domains (WHOQOL-BREF) and physical activity level (IPAQ) and independence (Lawton Scale) showed significantly moderate relationships between these variables.

The greater the weekly physical activity level (intensive and moderate), the better the quality of life in all four domains was assesed (Table 5). Also the higher scores on Lawton Scale of independence the higher quality of life in all four domains was noted. The strongest relationship was demonstrated for the physical domain which means that the more independent women, the more satisfied they are with their quality of life and especially with their life energy, readiness to work and rest (physical domain) (Table 5).

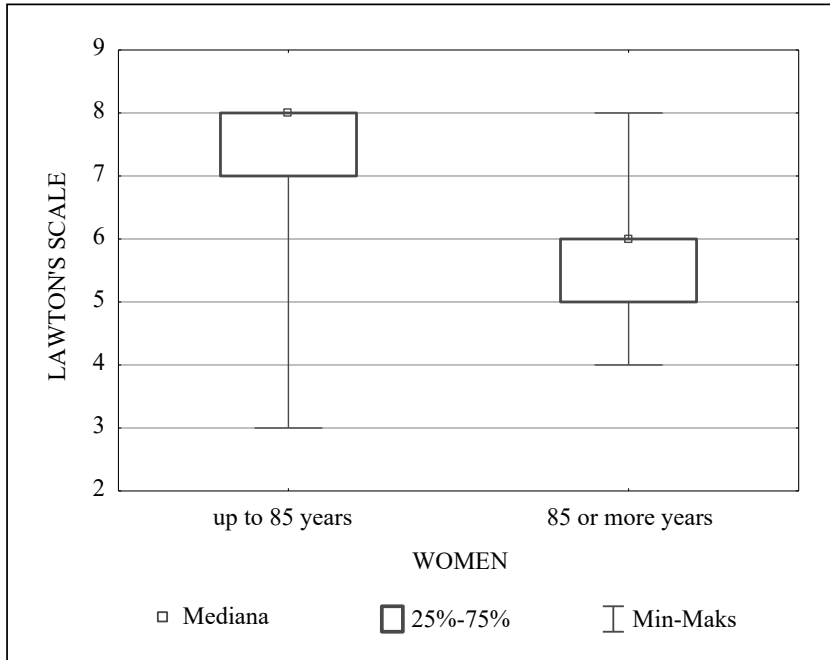

Figure 5. Statistical characteristics of independence in everyday life activities (Lawton Scae) for the two age groups of women surveyed)

\section{DISCUSSION}

The aging process cannot be stopped, but it is possible to slow down its progression. For elderly population the emphasis should be placed not only on the physical health (disease diagnosis and treatment, symptoms relief), but also on the quality of life, selfmaintenance and mobility $[25,28]$.

An important element of functioning and healthy aging is the functional fitness [35] which is the independence from others in satisfying basic life needs, and the ability to self-care. It includes: mobility, nutrition, controlling physiological functions and personal hygiene [2]. The level of independence in everyday activities and self-care of elderly depends on mental and physical condition [37].

Table 5. Relationships between the quality of life in four domains (WHOQOL-BREF) and the independence (Lawton Scale) and physical activity level (IPAQ). The correlation coefficients highlighted in bold are statistically significant with $\mathrm{p}<0.05$.

\begin{tabular}{|l|c|c|c|c|}
\hline \multicolumn{1}{|c|}{ WHOQOL-BREF } & Lawton's Scale & $\begin{array}{c}\text { IPAQ } \\
\text { high activity }\end{array}$ & $\begin{array}{c}\text { IPAQ } \\
\text { moderate activity }\end{array}$ & $\begin{array}{c}\text { IPAQ } \\
\text { low activity }\end{array}$ \\
\hline physical domain & 0.59 & 0.44 & 0.57 & 0.36 \\
\hline psychological domain & 0.52 & 0.36 & 0.48 & 0.27 \\
\hline social domain & $\mathbf{0 . 4 0}$ & $\mathbf{0 . 3 4}$ & $\mathbf{0 . 4 9}$ & 0.18 \\
\hline environmental domain & $\mathbf{0 . 4 0}$ & $\mathbf{0 . 2 8}$ & $\mathbf{0 . 2 8}$ & 0.16 \\
\hline
\end{tabular}


Our results show that women aged 80 and more living in the countryside are mostly independent. Living in own household in the rural area reinforces staying mobile because of i.e. the difficulty in access to shops or all kinds of institutions and the lack or inefficient public transportation. Bien et al. [1] emphasizes that the main reason that causes dependence on other people in daily care results from the mobility limitations. In the studies of Fidecki et al. [8] seniors from the rural environment showed better efficiency in everyday activities than people from the urban environment.

Based on our results, it can be concluded that the studied population of women over 80 showed no deficiencies in self-care abilities and required no help from others in daily activities. Also we found the relationship between efficiency in complex everyday activities and the assessment of the quality of life by the respondents. The more independent people were, the more they were satisfied with their own lives.

In this study, the physical activity was assessed with the IPAQ questionnaire as the activities from the last week preceding the day of the study. The results showed that $50 \%$ women declared moderate activity level and only $25 \%$ high activity level. The energy expenditure, which generated moderate physical activity, was related to work at home and around the house, mosty on typical housekeeping work in the home and in the garden. Similar results were obtained by Skotnicka and Pieszko [36] in a study of people over 80 years old, where the majority of respondents also showed moderate levels of physical activity.

Review of publications and the results of our research confirm the phenomenon that physical activity of the respondents decreases with age both among women and men [15, 17, 36, 40] In addition, Talbot et al. [41] noticed a change in the level of intensity of exercise with age, from intensive and moderate in adultery to low intensity exercise in the elderly. In our study almost all participants declared performing low level activities, mostly in the means of walking at least 10 minutes in one time. However, this type of activity might not enough to maintain good physical fitness. The World Health Organization and the American College of Sports Medicine recommend regular exercise more intensive than walking $[4,26$, 45]. Maintaining high physical fitness in old age is one of the factors that predicts the length of life and enables older people to maintain independence and autonomy [17]. Any type of physical exercise is better than hypokinesia, so older people who engage in any form of physical activity will always have some health benefits $[4,33]$.

Analysis of the quality of life profile for each domains of the WHOQOL-Bref questionnaire showed that older women gave highest scores in the domains of social relations and environment, while the physical domain obtained the lowest scores. In the research by Zboina et al. [46, 47] elderly women living in long-term care units also scored the lowest in the physical domain. Ćwirlej-Sozańska et al. [6] found a higher quality of life in all domains of the WHOQOL-Bref questionnaire in seniors living in rural areas, and the score was higher for seniors physically and socially active.

The quality of life of older people depends, among others, on the conditions and place of residence [9]. Participants in our study who stayed in their own households rated their quality of life at a good level. Also older women living in rural areas scored higher in the health self-assesment and quality of life than women living in cities. Similarly, in the research by Traczyk et al. [42], Grzegorczyk et al. [14], a higher assessment of the quality of life in most domains were found in seniors living independently than living in daily-care units or senior houses. Chruściel et al. [5] showed that seniors living in rural areas in their own household together with family members scored higher on life quality then seniors living independently but alone. Comparable results were delivered in the study of Garbaccio et al. [10] who showed high life quality and satistaction, that correlated with living in rural areas in own household with family members, and with financial independence and access to services including medical support when needed.

On the other hand Karwat et al. [20] and Pędlich [31], have different results, where the residents of cities assessed their life satisfaction more positively than rural residents. However it was correlated with higher disabilities and lower health status of surveyed seniors.

One of the most important predictors affecting the quality of life is the age of surveyed seniors $[12,27,29]$. In our research the age also turned out to be a significant factor influencing the assessment in the physical, psychological domain and self-assessment of health, where women above 85 years old showed decrease in physical performance, self-maintanance and overall life quality.

The conductance of our research was associated with certain limitations. The respondents assessed their independence in everyday activities, physical activity, quality of life in a subjective way, and, as in all surveys assessing health-related behaviour and lifestyle, the tendency to show oneself in a better light may be important factor that influences the results. Despite the presented limitations, our results bring new content into the area of issues related to the quality of life of women in old age. In addition, our research was conducted mostly in rural areas, among the elderly women living in their households, which is undoubtedly an important practical aspect in the field of seniors studies. 


\section{CONCLUSIONS}

Our study shows that women aged 80-84 assess their quality of life higher, are more independent in everyday activities and are more physically active than women aged 85 and more. Age significantly affects the assessment of the quality of life in the field of physical, psychological and self-assessment of health. The physical activity level has the strongest relation to quality of life and ability to self-care. However most women in old age showed moderate and low level of physical activity (mosty walking and housekeeping) which is not aimed at increasing physical fitness per se. It is recomended that more education and action should be aimed to increase the physical fitness of elderly women.

\section{Conflict of interst}

All authors claim no conflict of interest.

\section{REFERENCES}

1. Bień B., Wojszel Z., Wilmańska J., Polityńska B.: Epidemiologiczna ocena rozpowszechnienia niesprawności funkcjonalnej u osób w późnej starości a świadczenie opieki [Epidemiological assessment of the prevalence of functional disability in people in old age and the provision of care]. Gerontologia Polska 1999; 2: 42-47. (in Polish)

2. Biercewicz M., Kędziora-Kornatowska K., Ślusarz R., Cegła B., Faleńczyk K:: Ocena wydolności czynnościowej osób w wieku podeszłym na tle uwarunkowań zdrowotnych i społecznych [Assessment of the functional capacity of the elderly according to health and social conditions]. Pielęgniarstwo XXI wieku 2005; 1/2(10/11): 39-45. (in Polish)

3. Biernat E., Stupnicki R., Gakewski A.: Międzynarodowy Kwestionariusz Aktywności Fizycznej (IPAQ)- wersja polska [International Physical Activity Questionnaire (IPAQ) - Polish version]. Wychowanie Fizyczne i Sport 2007; 51(1): 47-54. (in Polish)

4. Brandão G.S., Oliveira L.V.F., Brandão G.S.: Effect of a home-based exercise program on functional mobility and quality of life in elderly people: protocol of a single-blind, randomized controlled trial. Trials. 2018;19(1):684. Published 2018 Dec 12. doi:10.1186/ s13063-018-3061-1

5. ChruścielP., SzczekalaK.M., Derewiecki T., Jakubowska K., Nalepa D., Czekirda M. E. et al. Differences in the quality of life dependent on family status of the elderly living in rural areas - a cross-sectional survey. Ann Agric Environ Med. 2018;25(3):532-538. doi:10.26444/ aaem/93501.

6. Ćwirlej-Sozańska A. B., Sozański B., WiśniowskaSzurlej A., Wilmowska-Pietruszyńska A.: Quality of life and related factors among older people living in rural areas in south-eastern Poland. Ann Agric Environ Med. 2018;25(3):539-545. doi:10.26444/aaem/93847.
7. Felce D., Perry J.: Quality of life: its definition and measurement. Res Dev Disabil. 1995 JanFeb;16(1):51-74.

8. Fidecki W., Wysokiński M., Wrońska I., Ślusarz $R .:$ Niesprawność osób starszych wyzwaniem dla opieki pielęgniarskiej [The disability of the elderly is a challenge for nursing care]. Problemy Pielęgniarstwa 2011; 19(1):1-4. (in Polish)

9. Gajewski T., Woźnica I., Młynarska M., Ćwikta S., Strzemecka J., Bajor I.: Wybrane aspekty jakości życia osób ze zmianami zwyrodnieniowymi kręgosłupa i stawów [Selected aspects of the quality of life of people with degenerative changes in the spine and joint]. Medycyna Ogólna i Nauki o Zdrowiu 2013; 19(3): 362-369. (in Polish)

10. Garbaccio J.L., Tonaco L.A.B., Estêvão W.G., Barcelos $B . J$ : Aging and quality of life of elderly people in rural areas. Rev Bras Enferm. 2018;71 Suppl 2:724-732. doi: 10.1590/0034-7167-2017-0149.

11. Górna K., Jaracz K.: Jakość życia osób starszych [The quality of life of the elderly]. in.: WieczorkowskaTobis K., Talarska D. red. Geriatria i pielęgniarstwo geriatryczne [Geriatrics and geriatric nursing]. Wydawnictwo Lekarskie PZWL 2008;343-345. (in Polish)

12.Gracia E.L., Banegas J.R., Pérez-Regadeva A.G., Cabrera R.H., Rodviguez-Artalejo F.: Social network and health-related quality of life in older adults: a population-based study in Spain. Qual Life Res Int J Qual Life Asp Treat Care Rehabil 2005; 14(2): 511-520.

13. Graf C.: The Lawton Instrumental Activities of Daily Living (IADL) Scale. Med surg Nurs. 2009 SepOct;18(5):315-6.

14. Grzegorczyk J., Kwolek A., Bazarnik K., Szeliga E., Wolan A.: Jakość życia osób mieszkających w domach pomocy społecznej i słuchaczy uniwersytetu trzeciego wieku [Quality of life of people living in nursing homes and attending the senior university lectures]. Przegląd Medyczny Uniwersytetu Rzeszowskiego 2007; 3: 225233. (in Polish)

15. Ham S.A., YoreM.M., Fulton J.E., Kohl H.W.: Prevalence of No Leisure-Time Physical Activity - 35 States and the District of Columbia, 1988-2002, Morbidity and Mortality Weekly Reports 2004; 51(4): 82-86.

16. Jarczak K.: WHOQOL-Bref. W: Wolowicka L. red. Jakość życia w naukach medycznych [Quality of life in medical sciences]. Akademia Medyczna im. K. Marcinkowskiego 2001;276-280. (in Polish)

17. Kaczmarczyk M., Trafiałek E.: Aktywizacja osób w starszym wieku jako szansa na pomyślne starzenie [Activation of older people as a chance for successful aging]. Gerontologia Polska 2007; 4(15):116-118. (in Polish)

18. Karimi M., Brazier J.: Health, Health-Related Quality of Life, and Quality of Life: What is the Difference? Pharmacoeconomics. 2016 Jul;34(7):645-9. doi: 10.1007/ s40273-016-0389-9.

19. Karski J., Stońska Z., Wasilewski B.W.: Promocja zdrowia: wprowadzenie do zagadnień krzewienia zdrowia [Health promotion: introduction to health 
promotion]. SANMEDIA, wyd 2, Warszawa 1994. (in Polish)

20.Karwat I., Karski A.: Poziom komfortu życia osób niepełnosprawnych zależnie od środowiska rodzinnego i społecznego [The level of comfort of life for people with disabilities depending on the family and social environment.]. In: Solecki L. (red.) Problemy ludzi starszych i niepełnosprawnych w rolnictwie. [Problems of elderly and disabled people in agriculture]. Wyd. IMW, Lublin 2004; 174-185. (in Polish)

21. Kim Y., Lee E.: The association between elderly people's sedentary behaviors and their health-related quality of life: focusing on comparing the young-old and the old-old. Health Qual Life Outcomes. 2019;17(1):131. Published 2019 Jul 26. doi:10.1186/s12955-019-1191-0

22.KocembaJ., Kołomyjska G.: Gerontologia [Gerontology]. Wydawnictwo AWF 1989. (in Polish)

23.Lara J., Godfrey A., Evans E., Heaven B., Brown L.J., Barron E., Rochester L., Meyer T.D., Mathers J.C.: Towards measurement of the Healthy Ageing Phenotype in lifestyle-based intervention studies. Maturitas. 2013 Oct;76(2):189-99. doi: 10.1016/j.maturitas.2013.07.007.

24.Lawton M.P., Brody E.M.: Assessment of older people: Self-maintaining and instrumental activities of daily living. Gerontologist, 1969,9(3), 179-186

25.Lewandowska A.: Expectations of nursing homes pensioners. In: Olchowik G. (red.) Wellness in different phases of life. Neuro Centrum, Lublin 2008; 115-119.

26. Mazurek J., Szczygiet J., Blaszkowska A., Zgajewska $K$., Richter W., Opara J.: Aktualne zalecenia dotyczące aktywności ruchowej osób w podeszłym wieku [Current recommendations for physical activity for older adults]. Gerontologia Polska 2014, 2, 70-75. (in Polish)

27. McBurney C.R., Eagle K.A., Kline-Rogers E.M., Cooper J.V., Mani O.C.M., Smith D.E. et al.: Health-related quality of life in patients 7 months after a myocardial infarction: factors affecting the Short Form-12. Pharmacotherapy 2002; 22(12): 1616-1622.

28. Molesztak A.: Jakość życia ludzi starych w aspekcie ich zdrowia [The quality of life of old people in the aspect of their health.]. In: J.T. Kowalewski, P. Szukalski (red.) Pomyślne starzenie się w perspektywie nauk społecznych i humanistycznych [Successful aging in the perspective of social sciences and humanities]. Łódź 2008; 50-65. (in Polish)

29. Muszalik M., Bartuzi Z., Kędziora-Kornatowska K.: Jakość życia chorych przewlekle w badaniach profile zdrowia [Quality of life of chronically ill patients in health profile research]. Ann UMCS Lublin 2006;60:8589. (in Polish)

30.Muszalik M., Kędziora-Kornatowska K.: Jakość życia przewlekle chorych pacjentów w starszym wieku [Quality of life for the chronically ill elderly]. Gerontologia Polska 2007;4:185-189. (in Polish)

31. Pędlich $W$ : Zróżnicowanie warunków życia i sytuacji socjalnej ludzi starszych na wsi [Diversity of living conditions and social situation of elderly people in the countryside] In: Solecki L. (red.) Problemy ludzi starszych i niepełnosprawnych w rolnictwie [Problems of elderly and disabled people in agriculture]. Wyd. IMW, Lublin 2004; 26-36. (in Polish)
32.Pinho J.P., Forner-Cordero A., Rodrigues Pereira R.M.: A High-Intensity Exercise Intervention Improves Older Women Lumbar Spine and Distal Tibia Bone Microstructure and Function: A 20-Week Randomized Controlled Trial. IEEE J Transl Eng Health Med. 2020;8:2100108. Published 2020 Jan 3. doi:10.1109/ JTEHM.2019.2963189

33. Podstawski $R$, Omelan A.: Deficyty ruchowe osób starszych - znaczenie aktywności fizycznej w ich zapobieganiu [Elderly movement deficits - the importance of physical activity in their prevention]. Hygeia Public Health 2015; 50(4): 572-580. (in Polish)

34.Rezuş E., Burlui A., Cardoneanu A., Rezuş C., Codreanu C., Pârvu M., RusuZota G., Tamba B.I.: Inactivity and Skeletal Muscle Metabolism: A Vicious Cycle in Old Age. Int. J. Mol. Sci. 2020, 21, 592. https://doi. org/10.3390/ijms21020592

35. Rybka M,. Rezmerska .L, Haor B.: Ocena sprawności osób w wieku podeszłym [Evaluation of the fitness of the elderly]. Pielęgniarstwo w Opiece Długoterminowej 2016; 2: 4-12. (in Polish)

36.Skotnicka M., Pieszko M.: Aktywność fizyczna receptą na długowieczność [Physical activity as a recipe for longevity]. Medycyna ogólna i Nauki o Zdrowiu 2014; 20(4): 379-383. (in Polish)

37. StrugałaM., TalarskaD.:Ocenasprawnościpodstawowej osoby w wieku podeszłym z wykorzystaniem katalogu czynności życia codziennego [Assessment of basic fitness of the elderlyusing the catalog of everyday activities]. Family Medicine \& Primary Care Review 2006; 8(2): 332-335(in Polish)

38. Szewczyczak M., Stachowska M., Talarska D.: Ocena jakości życia osób w wieku podeszłym - przegląd piśmiennictwa [Evaluation of the quality of life of the elderly - a review]. Nowiny Lekarskie 2012;81(1):96100. (in Polish)

39. Szpakow A., Klinackaya L.: Ocena wybranych aspektów jakości życia kobiet w wieku 45-60 lat - wykładowców uczelni wyższych z Grodna i Krasnojarska [Evaluation of selected aspects of the quality of life of women aged 45-60 years - university lecturers from Grodno and Krasnoyarsk]. Probl Hig Epidemiol 2009; 90(4):565568. (in Polish)

40.Szymczak M., Skrzek A.: Analiza związku codziennej aktywności fizycznej i składu ciała osób starszych [Analysis of the relationship of daily physical activity and body composition of the elderly]. Alter Ego Seniora 2014; 1(2): 34-39. (in Polish)

41. Talbot L.A, Metter E.J, Fleg J.L.: Leisure-time physical activities and their relationship to cardiorespiratory fitness in healthy men and women 18-95 years old. Med. Sci. Sports Exerc 2000; 32(2): 417-425.

42. Traczyk J, Kędzia P, Skrzek A.: Jakość życia, sprawność funkcjonalna oraz występowanie ryzyka depresji u kobiet po 60 roku życia mieszkających w domach opieki społecznej i samodzielnie [Quality of life, functional fitness and the risk of depression in women over 60 years of age living in social care homes and on their own]. Gerontologia Polska 2016; 24: 32-39. (in Polish) 
43. Vanleerberghe P., De Witte N., Claes C., Schalock R.L., Verté D.: The quality of life of older people aging in place: a literature review. Qual Life Res. 2017 Nov;26(11):2899-2907. doi: 10.1007/s11136-017-1651-0.

44. Witowski J.: Charakterystyka procesu starzenia [Characteristics of the aging process]. In.: Wieczorkowska-Tobis K., Talarska D. red. Geriatria i pielęgniarstwo geriatryczne [Geriatrics and geriatric nursing]. Wydawnictwo Lekarskie PZWL 2008;17-25. (in Polish)

45. World Health Organization: Obesity: preventing and managing the global epidemic. Report of a WHO consultation on obesity. World Health Organization. Geneva (CH) 1998.
46.Zboina B., Kulik T., Pacian A., Rudnicka-Drożak E.: Biopsychosocial factors shaping perception of quality of life of elderly people in long term care. Pol J Environ Stud 2006; 15(2a): 940-944.

47. Zboina B., Kulik T:: Uwarunkowania społeczne jako determinanty zadowolenia z jakości życia w zakładach pielęgnacyjno-leczniczych [Social conditions as determinants of satisfaction with the quality of life in nursing and treatment institutions]. In: Zboina $B$. (red.) Ostrowieckie Dni Promujące Zdrowie. WSBiP. Ostrowiec Świętokrzyski 2005; 79-90. (in Polish)

Received: 11.02 .2020

Accepted: 15.04 .2020 